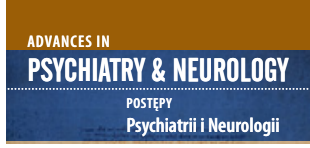

Correspondence to/Adres do korespondencji:

Ewa Taracha

Department of Neurochemistry

Institute of Psychiatry and Neurology

9 Sobieskiego St.

02-957 Warsaw, Poland

e-mail: taracha@ipin.edu.pl

Submitted/Otrzymano: 01.07.2021

Accepted/Przyjęto do druku: 05.11.2021

\section{The role of serotoninergic system in psychostimulant effects}

\author{
Rola układu serotoninergicznego \\ w działaniu substancji \\ psychostymulujących
}

\author{
Ewa Taracha
}

Department of Neurochemistry, Institute of Psychiatry and Neurology, Warsaw, Poland

\begin{abstract}
Purpose: This article discusses the modulatory effects of the serotonergic system on the behavioral and neurochemical effects exerted by psychostimulants, mainly cocaine.

Views: The mesocorticolimbic dopaminergic system plays an important role in the rewarding effects of psychostimulants and the long-lasting neuroadaptive changes underlying the development of addiction. Dopaminergic brain regions such as the ventral tegmental area (VTA) and substantia nigra (SN) and their projection fields (prefrontal cortex - PFC, nucleus accumbens - Acb, dorsal striatum) are innervated by serotonergic neurons that can modulate this system. Pharmacological manipulation of the activity of the serotonergic system in rats has shown that lowering or elevating its activity increases and decreases, respectively, most

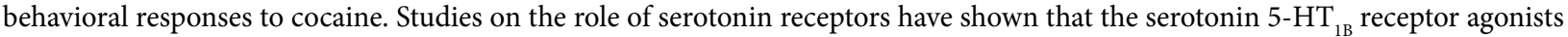
administered to the Acb during self-administration increase the reinforcing effects of cocaine, whereas when administered during abstinence they decrease cocaine seeking. Distinct populations of 5- $\mathrm{HT}_{2 \mathrm{AR}}$ and $5-\mathrm{HT}_{2 \mathrm{CR}}$ in the PFC, Acb, and VTA differentially affect the output of the mesocorticolimbic dopaminergic pathway. $5-\mathrm{HT}_{2 \mathrm{~B}}$ receptors exert independent control over the activity of the three ascending dopamine (DA) pathways through specific tonic excitatory and inhibitory control of DA efflux from the Acb and PFC and do not affect striatal activity.

Conclusions: The serotonergic system exerts modulatory effects on the behavioral and neurochemical effects of psychostimulants. The pharmacological manipulation of serotonergic system activity makes it possible to attenuate the effects of psychostimulants, which gives hope for the development of effective pharmacotherapy. Currently, the main obstacle to this is the excessive side effects shown by potential drugs.
\end{abstract}

Key words: dopamine, serotonin, serotonin receptors, psychostimulants.

\title{
Streszczenie
}

Cel: W artykule omówiono modulujący wpływ układu serotoninergicznego na behawioralne i neurochemiczne efekty wywierane przez substancje psychostymulujące, głównie kokainę.

Poglądy: Mezokortykolimbiczny układ dopaminergiczny odgrywa istotną rolę w nagradzającym działaniu psychostymulantów oraz w powstawaniu długotrwałych zmian neuroadaptacyjnych leżących u podstaw rozwoju uzależnienia od tych substancji. Dopaminergiczne regiony mózgu, takie jak pole brzuszne nakrywki (VTA) i substancja czarna (SN), oraz ich pola projekcyjne (kora przedczołowa - PFC, jądro półleżące - Acb, prążkowie grzbietowe) są unerwione przez neurony serotoninergiczne, które mogą modulować ten układ. Wykazano, że manipulacje farmakologiczne aktywnością układu serotoninergicznego u szczurów, prowadzące do zmniejszenia lub zwiększenia jego aktywności, powodują odpowiednio nasilenie i zahamowanie większości reakcji behawioralnych w odpowiedzi na kokainę. Badania nad rolą receptorów serotoninowych wykazały, że agonisty receptorów serotoniny 5- $\mathrm{HT}_{1 \mathrm{~B}}$ podawane do Acb w czasie samopodawania zwiększają wzmacniające działanie kokainy, natomiast gdy są podawane w czasie abstynencji, zmniejszają poszukiwanie kokainy. W przypadku receptorów $5 \mathrm{HT}_{2}$ wykazano, że odrębne populacje 5 - $\mathrm{HT}_{2 \mathrm{AR}}$ i 5- $\mathrm{HT}_{2 \mathrm{CR}} \mathrm{w}$ PFC, Acb i VTA w różny sposób wpływają na wyjście mezokortykolimbicznego szlaku dopaminergicznego, a receptory $5-\mathrm{HT}_{2 \mathrm{~B}}$ wywierają niezależną kontrolę nad aktywnością trzech wstępujących szlaków dopaminy (DA) poprzez specyficzną toniczną kontrolę pobudzającą i hamującą odpływ DA z Acb i PFC, ale nie wpływają na aktywność prążkowia.

Wnioski: Układ serotoninergiczny wywiera modulujący wpływ na behawioralne i neurochemiczne efekty substancji psychostymulujących. Manipulacje farmakologiczne aktywnością układu serotoninergicznego pozwalają na osłabianie efektów wywieranych przez psychostymulanty, co daje nadzieję na opracowanie skutecznej farmakoterapii. Na razie zasadniczą przeszkodą są zbyt ciężkie działania niepożądane wykazywane przez potencjalne leki.

Słowa kluczowe: dopamina, serotonina, receptory serotoninowe, substancje psychostymulujące. 
The role of serotoninergic system in psychostimulant effects

Rola układu serotoninergicznego $w$ działaniu substancji psychostymulujacych

\section{INTRODUCTION}

Drugs of abuse have many valuable properties and are used in therapy, e.g. morphine is a very good painkiller, amphetamine derivatives are used to normalize attention deficit disorder and to treat narcolepsy [1], and cocaine is used in nose and eye surgery [2]. However, these substances usurp the right to act in reward, motivation and memory circuits, and their abuse can lead to pathological neuroadaptive changes and, in susceptible individuals, to the development of addiction.

The hallmark of addictive substances is their rewarding effects. The rewarding effects of almost all addictive substances are associated with three ascending dopaminergic pathways: the nigrostriatal, the mesocortical, and the mesoaccumbal dopaminergic tracts $[3,4]$. The mesocorticolimbic dopaminergic network may be critical not only for reward properties following acute administration of psychostimulant drugs but also for long-term neuroadaptive changes in the brain responsible for behaviors characteristic of drug addiction, particularly cocaine addiction [5-8]. The rapid release of dopamine (DA) induced by psychostimulants is associated with the subjective sensation of the so-called "high" [9]. Rapid changes in DA levels activate dopamine $\mathrm{D}_{1}$ receptors with low affinity. Their activation is essential for the development of the rewarding effects of drugs [10] and the production of conditioning [11]. There also appears stimulation of high-affinity $\mathrm{DA} \mathrm{D}_{2}$ receptors, but their stimulation is not sufficient to produce a rewarding effect $[12,13]$, and these receptors can even reduce reward perception $[14,15]$.

With the development of addiction, cognitive and motivational disturbances arise. Structures of dopaminergic limbic-cortical circuits, such as ventral tegmental area (VTA), medial prefrontal cortex (mPFC), nucleus accumbens (Acb), and amygdala (Amy) are involved in these processes [16]. They are responsible for impulsivity and reactivity to stimuli. Neuroadaptations involving these areas are thought to be crucial in the development of addiction [1, 17]. The VTA is responsible for the initiation of behavioral sensitization, reward-motivated behavior, or anhedonia in acute withdrawal; the MPFC, which is responsible for inhibitory control, is the site where the effects of drugs of abuse lead to altered executive function and impaired decision making; the Acb is responsible for reward action, maintenance of sensitization, and persistent drug-induced behavior; the Amy is associated with memory for the motivational impact of drug-associated stimuli $[16,18,19]$. Substances of abuse are associated with rewards, which have hedonic ("liking") and motivational ("wanting") values and drug intake is accompanied by the learning of associations between reward and drug-associated stimuli [20]. The value of natural rewards and the motivational aspects of intracranial self-stimulation-induced reward is controlled by serotonergic innervation of the limbic-corticostriatal circuit $[21,22]$.

5-HT plays an essential role in, among other things, associative learning, a process important for drug use behavior. It is exploited in a classic test for studying reward action, the conditioned place preference (CPP) test, in which animals learn to associate specific environment with a drug-related context. Drug-altered serotonin neurotransmission can contribute to vulnerability and altered neurobiological states that result in the transition from controlled use, through abuse, to addiction [23]. Serotonergic neuroadaptive changes induced by just the first dose of a drug can contribute to the development of addiction [24].

Two serotonergic pathways extending from their parent neurons from the raphe nuclei, the dorsal raphe nucleus (DRN) and median raphe nucleus (MNR), innervate cortical and subcortical structures [23]. These 5-HT neurons intensely innervate the forebrain (hippocampus, hypothalamus, substantia nigra $(\mathrm{SNc})$, medial mammillary nucleus, lateral septum, thalamus, AMY, and cortex) [25]. Dopaminergic brain regions such as the SNc and VTA, as well as their terminal fields (dorsal striatum, Acb, and frontal cortex; see above), are thus innervated by the 5 -HT system $[25,26]$. Hence the interest in the role of the serotonergic system in the emergence of behaviors associated with controlled drug use, the transition to compulsive use, and the development of addiction in which the dopaminergic system plays a key role.

It has been shown that increasing and decreasing 5-HT transmission can decrease and increase, respectively, the ability of drugs such as cocaine to elicit a dopaminergic response $[27,28]$. Most psychostimulants with addictive potential have been shown to increase 5-HT activity in almost the entire brain. Psychostimulants bind to the serotonin transporter (SERT), which leads to the inhibition of 5-HT reuptake and increased extracellular 5-HT outflow $[29,30]$. This has significant effects on the cellular activity of raphe 5-HT neurons $[31,32]$ and neuronal signaling in terminal regions of raphe 5-HT neurons, such as cortical areas [33-35]. Thus, cocaine exposure significantly alters the function of $5-\mathrm{HT}$ neurons and 5-HT signaling in limbic-cortical-striatal circuits and is thought to affect 5-HT neurons' control of reward signal processing. Based on electrophysiological studies in monkeys [36], 5-HT DRN neurons have been shown to transmit reward-related information to the forebrain, and in studies in rats they have been shown to influence reward-seeking behavior [37-39].

Cocaine has been shown to cause 5HT release from the Acb [40, 41], dorsal striatum [33], ventral pallidum [42], hippocampus [41, 43], thalamus [44], hypothalamus, VTA [34, 45], and DRN [34]. Cocaine also increases extracellular 5-HT levels in several areas of the new cor- 
tex, such as the PFC $[35,46]$, the occipital and temporal cortices [47], and the entorhinal and perirhinal cortices. Taken together, acute cocaine administration increases extracellular 5-HT levels in the brain. Repeated cocaine administration may lead to increased SERT activity in terminal fields and decreased tissue and extracellular 5-HT levels in these areas. Also, AMPH increases extracellular 5-HT levels in the Acb and striatum [48-51], in the frontal cortex (FC) [52], PFC [35, 52], and entorhinal and perirhinal cortex, in parallel with locomotor activation [53]. During local intra-DRN administration of AMPH [54], increased levels of extracellular 5-HT were observed in the DRN but not in the striatum [55]. Local application of AMPH by reverse dialysis to the infralimbic and anterior cingulate subregions of the PFC also increased extracellular 5-HT levels in these regions [56]. Overall, acute administration of AMPH causes a significant increase in extracellular 5-HT levels in the brain. There is no evidence for up-regulation of SERT and a change in basal 5-HT levels after chronic use.

Serotonin (5-HT) has been shown to be essential not only for maintaining synaptic plasticity across the lifespan [57] but also for hedonic tone, motivation and reinforcement, and learning and memory [58]. Learning and memory, but also sensory processing $[52,59]$, temporally coincide with increased 5-HT activity. This analogy points to a functional role of brain 5-HT activation in the emergence of addiction.

\section{EFFECTS OF PHARMACOLOGICAL MANIPULATIONS OF 5-HT SYSTEM ACTIVITY ON THE EFFECTS OF PSYCHOSTIMULANTS}

In order to study the serotonergic mechanisms involved in the neurochemical and behavioral effects of psychostimulants, preclinical studies use pharmacological manipulations involving the administration to rats, peripherally or to selected brain structures, of substances that increase or decrease levels of 5-HT.

\section{Decreasing 5-HT levels}

Reducing 5-HT transmission may increase the behavioral effects of cocaine by increasing self-administration and enhancing cocaine-induced locomotor activity, CPP, and a goal-directed conditioned approach [27, 60]. The most commonly used approaches to lower serotonin levels include: (i) reducing the substrate for its synthesis by administering a tryptophan-deficient amino acid mixture (acute tryptophan depletion) orally (rats, humans); (ii) decreasing its synthesis by administering an inhibitor of tryptophan hydroxylase, the rate-limiting enzyme in serotonin synthesis (rats); (iii), depletion of serotonin by administration of the neurotoxin 5.7-dihydroxytryptamine (5.7-DHT) (rats).

Studies that lowered 5-HT levels in rats using the tryptophan hydroxylase inhibitor para-chlorophenylalanine $[61,62]$ showed an increase in cocaine-induced hyperlocomotion. A similar effect was also observed after the lesion of serotonergic neurons using 5.7-DHT [63]. In contrast, after intracerebroventricular (ICV) administration of the neurotoxin 5.7-DHT, decreased levels of 5-HT were observed in the midbrain but not in the Acb or Amy. This was accompanied by an increased breakpoint [64]. Lesions of specific regions allowed researchers to determine their contribution to the effects of 5-HT on psychostimulant effects. Local decreases in 5-HT in the medial forebrain or Amy resulted in an increased breakpoint [65], indicating that 5-HT innervation in the forebrain is crucial for cocaine reward. Administration of 5.7-DHT to the mPFC attenuated the hyperlocomotor effects induced by cocaine, whereas lesions in the entorhinal and occipital cortices had no effect [66]. Both global damage of 5-HT neurons induced with 5.7-DHT, and that restricted to the forebrain or amygdala nuclei, increased responding for cocaine in a fixe and progressive ratio schedule in rats [65].

In rats, a tryptophan-deficient diet significantly increases locomotor activity, CPP, and dopaminergic responses to amphetamine and cocaine [67-69]. In humans, a diet devoid of tryptophan also increased cocaine-induced "craving" for the drug [69] but suppressed the "high" [70]. Using PET $\left({ }^{11} \mathrm{C}\right)$ raclopride methods, it was shown that acute tryptophan depletion induced by the oral administration of a tryptophan-deficient amino acid mixture (acute tryptophan depletion) increased cocaine-induced drug seeking and striatal DA response to cocaine in cocaine-dependent humans $[69,70]$. These authors believe that the dopaminergic effects of cocaine under conditions of acute tryptophan deficiency show some neuroanatomical specificity. The ventral striatum receives dense input signals from the Amy, hippocampus, and limbic cortex. They are thought to be responsible for maintaining motivation to act in response to salient stimuli, such as drug reward $[1,71,72]$. In contrast, the dorsal striatum receives more stimuli from association and sensorimotor areas of the cortex and less from limbic areas. Dopamine within the dorsal striatum is implicated in stimulus-response habit learning [73]. This may suggest that limbic system-mediated incentive motivational processes extend gradually from the ventromedial striatum to more dorsal area [74]. At low concentrations of 5-HT, drug-induced dopaminergic responses are increased within the dorsal striatum, resulting in increased motivation for drug reward and susceptibility to compulsive drug-seeking (see Figure I).

In humans, decreased 5-HT levels decreased resting limbic DA levels and increased the cocaine-induced DA responseinthestriatumand the desiretotakethedrug [69]. 


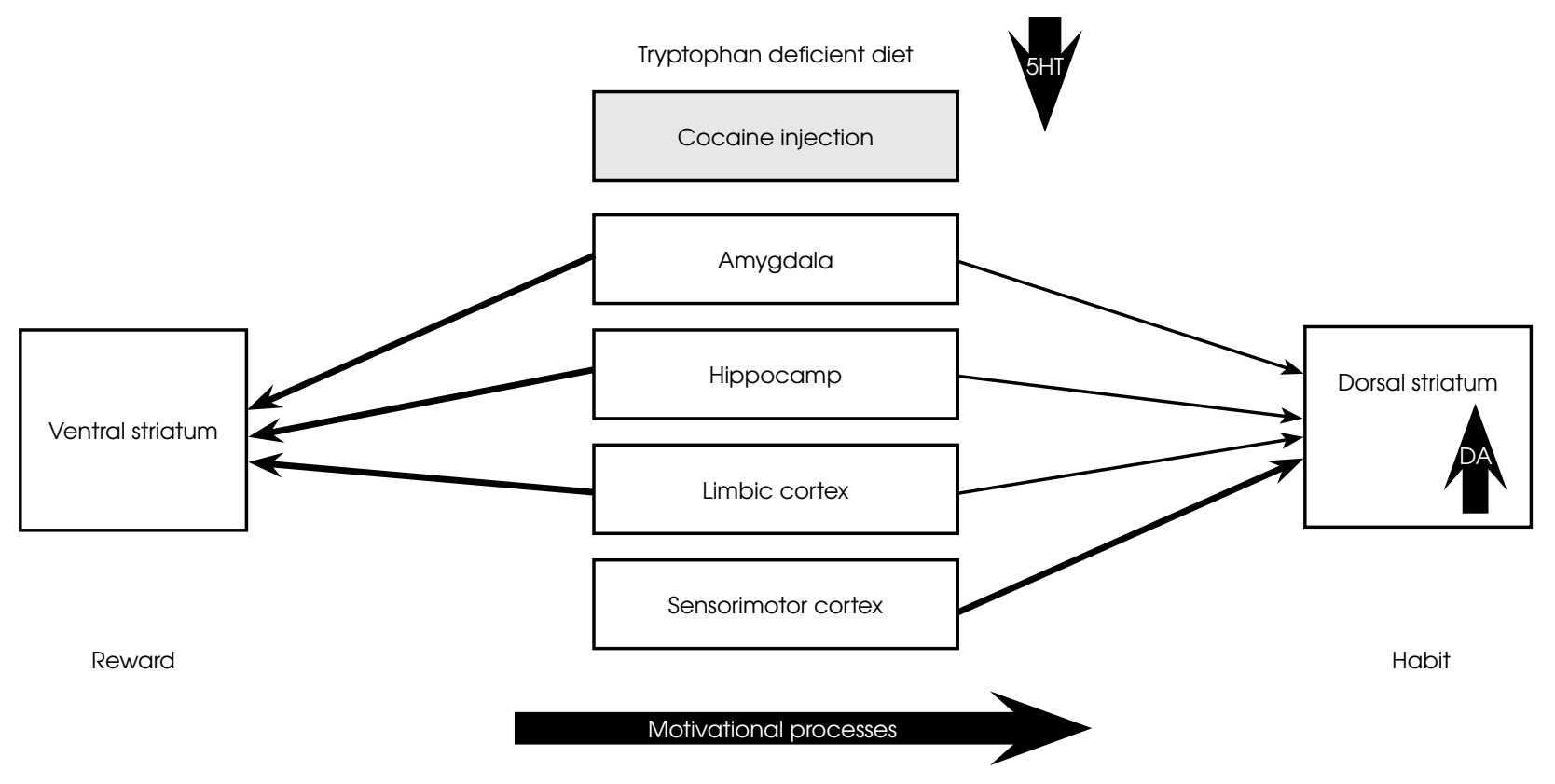

Figure I. Under condition of low concentration of 5-HT (tryptophan deficient diet), cocaine-induced dopaminergic responses are increased within the dorsal striatum resulting in increased susceptibility to compulsive drug seeking. Incentive motivational processes extend gradually from ventromedial striatum to more dorsal aspects

Most of the available studies done in rodents suggest that decreased tissue levels of 5-HT exacerbate most of the behaviors associated with cocaine use, such as hyperlocomotion, CPP, and self-administration relapse. This suggests that 5-HT suppresses cocaine use behaviors [23, 47]. However, it is essential to note that a systemic reduction in 5-HT does not necessarily equate to reducing the dynamic extracellular 5-HT response. In addition, the 5-HT synapse becomes hypersensitive to dynamic increases in 5-HT and responds with greater signal throughput to acute cocaine administration. While basal 5-HT tissue levels are reduced, the 5-HT synapse is rendered supersensitive towards a dynamic 5-HT increase and responds now with enhanced signal throughput to acute cocaine administration. Besides this, lowering basal 5-HT levels can increase the expression and sensitivity of 5-HT receptors $[24,75]$.

Given that repeated cocaine administration coincides with a decrease in tissue levels of 5-HT but exacerbates cocaine use behavior compared to that observed after acute cocaine administration [24], it is speculated that the acute increase in extracellular 5-HT after cocaine is not necessarily required to induce cocaine-use behavior but is necessary to cause the up-regulation of SERT in terminal areas and down-regulation at a somatodendritic level. This ultimately leads to a down-regulation of basal 5-HT levels, which involves hyper-sensitization of the 5-HT receptors. It has been suggested that this scenario will promote the development and maintenance of various cocaine use behaviors [24].

\section{Increasing 5-HT activity}

In contrast, increasing 5-HT neurotransmission has the opposite effect, decreasing cocaine-induced dopaminergic responses and behaviors $[69,76,77]$. Increasing 5 -HT activity can be achieved by using a 5 -HT precursor such as L-tryptophan and, even better, 5-hydroxy-L-tryptophan, using serotonin reuptake inhibitors (SSRIs) or 5-HT releasing agents such as fenfluramine.

Pradhan and colleagues [78] found that 5-hydroxyL-tryptophan, a direct precursor of 5-HT, attenuates the locomotor response of cocaine in rats. Similar effects were obtained after administration of L-tryptophan [79]. Pretreatment with L-tryptophan decreased the breakpoint in a progressive ratio schedule of i.v. cocaine selfadministration in rats [80].

Also, administration of fenfluramine, which releases 5-HT [81], or the selective 5-HT reuptake inhibitor (SSRI) fluoxetine $[77,82,83]$ suppressed the reinforcing and motivational properties of cocaine. However, in other studies fluoxetine and fluvoxamine increased cocaine-induced locomotor activation $[62,84]$, although the administration of citalopram and sertraline was without effect [85]. The non-serotonergic mechanisms of action of fluoxetine appear to be responsible for the cocaine-enhancing effects of fluoxetine, as this effect was also observed in animals with 5.7-DHT-induced 5HT depletion [85].

In a study conducted in rhesus monkeys, PAL-434 (a 5-HT releasing substance) selectively reduced cocaine self-administration if the food was the choice [86]. 
The inhibitory effects of 5-HT on the motivational/ reinforcing effects of cocaine were also studied in SERT knock out (KO) in mice and rats. However, increased cocaine-induced CPP was observed in SERT KO mice and rats [87-89]. Compared to wild-type rats, the SERT-KO ones showed increased cocaine self-administration under short access conditions [87], and SERT-KO rats even escalated cocaine self-administration under long access conditions. Due to the lack of SERT and the associated lack of 5-HT reuptake, these rats have high extracellular 5-HT levels [90, 91]. However, tissue levels of 5-HT and 5-HIAA are lower in SERT-KO rats in the hippocampus, dorsal striatum, cerebral cortex and Amy, compared to wild-type rats [90]. Also, the electrically-evoked 5-HT release was lower in SERT-KO rats in the hippocampus, dorsal striatum, cortex and Amy [90]. Furthermore, such genetically altered rats showed more intense cocaineseeking during extinction sessions.

\section{THE ROLE OF 5-HT RECEPTORS IN THE EFFECTS OF PSYCHOSTIMULANTS}

The high density of 5-HT receptors in structures of the mesocorticolimbic system, which is central to the development of addiction, suggests that 5-HT may play an essential modulating role $[92,93]$. The role of the serotonergic system in the effects of addictive substances is complex. The action of 5-HT at the synapse is controlled by SERT; 5-HT neurotransmission is mediated by at least 14 different 5-HT receptor subtypes. These include 5-HT autoreceptors located at 5-HT nerve terminals that regulate 5-HT release $[94,95]$ as well as heteroreceptors located on dopaminergic terminals, dopaminergic, glutamatergic, GABAergic or cholinergic neurons that regulate the release of these neurotransmitters [96-98]. The 14 genetically encoded 5-HT receptor subtypes form seven families (5$\mathrm{HT}_{1 \mathrm{R}}-5-\mathrm{HT}_{7 \mathrm{R}}$ ) depending on their structural (mRNA and amino acid sequence homology) and functional (signal transduction mechanisms, pharmacological properties) properties (for review see $[99,100])$. A further example of a complication is that $5-\mathrm{HT}_{2 \mathrm{CR}}$ can form $32 \mathrm{mRNA}$ isoforms that can encode up to 24 different receptor protein isoforms in humans [101] and rats [102]. The $5-\mathrm{HT}_{3 \mathrm{R}}$ subtype is a ligand-gated ion channel, and the remaining 5-HTRs belong to a superfamily of receptors with seven transmembrane bands, more commonly referred to as $G$ protein-coupled receptors (GPCRs) [103].

\section{5- $\mathrm{HT}_{1 \mathrm{~B}}$ receptors}

$5-\mathrm{HT}_{1 \mathrm{~B}}$ receptors appear to play an important role in mediating the effects induced by psychostimulants. Results regarding the effects of serotonin-5- $\mathrm{HT}_{1 \mathrm{~B}}$ receptor manipulation on the various effects of cocaine appear divergent. 5- $\mathrm{HT}_{1 \mathrm{BR}}$ antagonists inhibit psychostimulant-in- duced locomotor activation [104-106] but 5- $\mathrm{HT}_{1 \mathrm{BR}} \mathrm{KO}$ mice show increased locomotor activation compared to wild-type mice [106]. Perhaps the reason for these differences is the different effects produced by acute pharmacological blockade and long-term genetic knockout of 5- $\mathrm{HT}_{1 \mathrm{~B}}$ receptors [105]. Interestingly, as mentioned above, the effects observed in SERT-KO animals were also opposite to those expected [24]. 5- $\mathrm{HT}_{1 \mathrm{~B}}$ receptor antagonists inhibit cocaine-seeking or cue-induced behaviors. Importantly, this effect of 5- $\mathrm{HT}_{1 \mathrm{~B}}$ receptor antagonists appears to be specific, as it does not affect other responses to cocaine (sensitization, CPP, self-administration maintenance), or food intake behaviors in rats [105]. In contrast, rats with an overexpression of 5-HT receptors showed increased cocaine reward for cocaine-induced CPP [107]. Acute pharmacological blockade of $5-\mathrm{HT}_{1 \mathrm{~B}}$ receptors did not affect cocaine self-administration in mice [104] and rats $[108,109]$, or amphetamine in rats [110]. It has been shown $[105,111]$ that the $5-\mathrm{HT}$ receptor antagonist GR 127935, administered at $3 \mathrm{mg} / \mathrm{kg}$, did not affect cueinduced cocaine relapse. However, the 5-HT receptor antagonist administered at a higher dose $(10 \mathrm{mg} / \mathrm{kg})$, and another antagonist, SB $216641(7.5 \mathrm{mg} / \mathrm{kg})$, strongly reduced psychostimulant-seeking behavior under cocaine provocation [112]. There are suggestions that these receptors undergo, bidirectional, changes dependent on abstinence status[113-115]. This is indicated by studies showing that $5-\mathrm{HT}_{1 \mathrm{~B}}$ receptor agonists administered to the Acb increase cocaine reinforcement during selfadministration and decrease cocaine-seeking and reoccurrence of cocaine-seeking behaviors when administered during abstinence $[114,115]$.

\section{5- $\mathrm{HT}_{2}$ receptors}

The $5-\mathrm{HT}_{2 \mathrm{R}}$ family consists of $5-\mathrm{HT}_{2 \mathrm{AR}}, 5-\mathrm{HT}_{2 \mathrm{BR}}$ and $5-\mathrm{HT}_{2 \mathrm{CR}}$, which share sequence homology, similar pharmacological properties, and signaling pathways $[99,100]$. The ultimate level of $5-\mathrm{HT}_{2 \mathrm{R}}$ functionality depends on many factors, including the availability of an active receptor pool and effective coupling and activation of signaling components.

These 5- $\mathrm{HT}_{2 \mathrm{AR}}$ and $5-\mathrm{HT}_{2 \mathrm{CR}}$ receptors control the neurochemical and behavioral effects of psychostimulants, particularly the effects of cocaine. Preclinical studies indicate that $5-\mathrm{HT}_{2 \mathrm{AR}}$ antagonists and/or $5-\mathrm{HT}_{2 \mathrm{CR}}$ agonists can effectively reduce drug craving and/or relapse as well as increase abstinence, while $5-\mathrm{HT}_{2 \mathrm{CR}}$ agonists can also effectively reduce cocaine intake in active cocaine users [116]. 5- $\mathrm{HT}_{2 \mathrm{AR}}$ and 5- $\mathrm{HT}_{2 \mathrm{CR}}$ play important stimulatory and inhibitory roles, respectively, in modulating cocaine and other psychostimulant-induced DA output. Systemic administration of $5-\mathrm{HT}_{2 \mathrm{CR}}$ antagonists potentiated cocaine-induced DA release in the Acb [117] and the selective 5- $\mathrm{HT}_{2 \mathrm{AR}}$ antagonist 
SR 46349B decreased cocaine [118] or amphetamineinduced DA release in it [119]. Consequently, these receptors can be expected to modulate behavioral effects induced by psychostimulants, in which dopaminergic mechanisms play a major role. The study of the neurobiological mechanisms of action of drugs often uses locomotor activation related to their ability to release DA in the Acb (for a review, see [120]). Acute systemic injections of selective $5-\mathrm{HT}_{2 \mathrm{AR}}$ antagonists and $5-\mathrm{HT}_{2 \mathrm{CR}}$ agonists at doses that did not themselves affect behavior have been shown to block the hyperlocomotor effects of cocaine. In contrast, the administration of 5- $\mathrm{HT}_{2 \mathrm{AR}}$ agonists and 5-HT ${ }_{2 \mathrm{AR}}$ antagonists enhanced them [121-124]. $5-\mathrm{HT}_{2 \mathrm{AR}}$ and $5-\mathrm{HT}_{2 \mathrm{CR}}$ ligands similarly affected the effects of amphetamine $[125,126]$ and its derivatives (MDMA; ecstasy) [110, 127, 128], even though these substances have different mechanisms of action. Furthermore, the effects of $5-\mathrm{HT}_{2}$ receptor manipulation have also been more similar for psychoactive substances other than psychostimulants, such as morphine, nicotine, and phencyclidine [116]. The effects of $5-\mathrm{HT}_{2 \mathrm{R}}$ agonists and antagonists on performance in other behavioral tests (drug discrimination, self-administration, cocaine reinstatement, cue reinstatement, CPP) were summarized in a review paper by Bubar and Cunningham [116]. The results indicate that $5-\mathrm{HT}_{2 \mathrm{AR}}$ receptors play an excitatory role and $5-\mathrm{HT}_{2 \mathrm{CR}}$ receptors an inhibitory role in the control of behavior induced by stimulant administration.

To identify the pathways and structures responsible for these effects, ligands specific for $5-\mathrm{HT}_{2 \mathrm{AR}}$ and $5-\mathrm{HT}_{2 \mathrm{CR}}$ were injected into different brain regions, starting at the DA mesocorticoaccumbens pathway's DA nodes: the VTA, Acb or PFC [116]. Ligands were administered at doses that do not alter baseline behavior [129-131] but do alter cocaine-induced behavior when microinjected into the nuclei of the mesocorticoaccumbens pathway immediately before systemic cocaine administration.

Microinjection of the selective $5-\mathrm{HT}_{2 \mathrm{AR}}$ antagonist M100907 into the VTA inhibited the locomotor stimulant and discriminative stimulus effects of cocaine [129], as well as neuronal activation in the nucleus accumbens shell (AcbSh) assessed by Fos protein expression induced by systemic cocaine administration [132]. Intra-VTA infusion of another 5- $\mathrm{HT}_{2 \mathrm{AR}}$ antagonist, SR 46349B, also blocked amphetamine-induced hyperactivity and amphetamine-induced DA release in the Acb [119]. In contrast, microinjection into the Acb of the selective 5- $\mathrm{HT}_{2 \mathrm{AR}}$ antagonist M100907 did not affect cocaine-induced hyperactivity [129]. These results suggest that the $5-\mathrm{HT}_{2 \mathrm{AR}}$ in VTA plays a pivotal role in controlling psychostimulant-induced hyperactivity, possibly through its effects on psychostimulant-induced efflux DA, but the role of the $5-\mathrm{HT}_{2 \mathrm{AR}}$ in Acb and PFC is not yet clear.
The 5- $\mathrm{HT}_{2 \mathrm{CR}}$ antagonist RS102221, administered into the VTA, did not alter cocaine-induced hyperactivity $[130,133]$, whereas the infusion of a $5-\mathrm{HT}_{2 \mathrm{CR}}$ agonist blocked it [85]. In contrast to the inhibitory effects of $5-\mathrm{HT}_{2 \mathrm{CR}}$ agonists in the VTA, an intra-AcbSh microinjection of the 5- $\mathrm{HT}_{2 \mathrm{CR}}$ antagonist RS 102221 attenuated, whereas infusion of the 5- $\mathrm{HT}_{2 \mathrm{CR}}$ agonist $\mathrm{MK}$ 212 or RO 60-0175 potentiated, the hyperlocomotor effects of cocaine in a dose-dependent manner [130, 133]. In contrast to that observed after systemic administration $[122,123]$, intra-mPFC microinjections of the $5-\mathrm{HT}_{2 \mathrm{CR}}$ agonist MK 212 or the antagonist RS 102221 decreased or increased the hyperlocomotor effects of cocaine, respectively [131]. The effects of 5- $\mathrm{HT}_{2 \mathrm{CR}}$ agonists, when administered systemically and to the PFC, are similar and exert inhibitory control over the hypermotor effects of cocaine. The use of microinjections of 5- $\mathrm{HT}_{2 \mathrm{CR}}$ ligands into individual structures indicate that $5-\mathrm{HT}_{2 \mathrm{CR}}$ in the Acb and PFC have to oppose stimulatory and inhibitory effects on the hyperlocomotor effects of cocaine, respectively. The effect induced by administration of $5-\mathrm{HT}_{2 \mathrm{CR}}$ ligands depends on the contribution and interplay of the different 5- $\mathrm{HT}_{2 \mathrm{CR}}$ populations located in the VTA, Acb, and $\mathrm{PFC}$, with the 5- $\mathrm{HT}_{2 \mathrm{CR}}$ population in the $\mathrm{PFC}$ appearing to have a dominant influence.

In summary, the results of microinjection studies indicate that while $5-\mathrm{HT}_{2 \mathrm{AR}}$ and $5-\mathrm{HT}_{2 \mathrm{CR}}$ in the mesocorticoaccumbens nuclei do not play an active tonic role in behavioral control, separate populations of 5- $\mathrm{HT}_{2 \mathrm{AR}}$ and 5- $\mathrm{HT}_{2 \mathrm{CR}}$ within the PFC, Acb, and VTA differentially affect the output of the mesocorticoaccumbens DA pathway. These studies indicate that the VTA is one of the sites in the brain in which $5-\mathrm{HT}_{2 \mathrm{AR}}$ exerts an excitatory effect on cocaine-induced behavior, whereas the PFC is a specific site in the brain in which $5-\mathrm{HT}_{2 \mathrm{CR}}$ exerts an inhibitory effect on cocaine-induced behavioral responses [131, 134]. However, further studies evaluating the involvement of $5-\mathrm{HT}_{2 \mathrm{AR}} \mathrm{s}$ and $5-\mathrm{HT}_{2 \mathrm{CR}} \mathrm{s}$ located in brain areas outside the mesocorticoaccumbens circuit are necessary to understand the specific sites of action of these areas' receptors throughout the brain.

$5-\mathrm{HT}_{2 \mathrm{BR}} \mathrm{s}$ also appear to play an important role in regulating both basal and "stimulated" DA activity. In particular, data available in the literature show that $5-\mathrm{HT}_{2 \mathrm{BR}} \mathrm{S}$ are able to regulate DA release and transmission, as well as DA-dependent behavior, through complex polysynaptic processes [135].

Locally differential effects of $5-\mathrm{HT}_{2 \mathrm{BR}}$ antagonists on dopaminergic activity in the MPFC and Acb have been demonstrated. This is likely due to a functional interaction of $5-\mathrm{HT}_{2 \mathrm{BR}}$ with $5-\mathrm{HT}_{1 \mathrm{AR}} \mathrm{s}$ involving cortical-subcortical pathways. It has been observed that the blockade of $5-\mathrm{HT}_{2 \mathrm{BR}}$ results in an increased cortical outflow of 5-HT, which stimulates 5- $\mathrm{HT}_{1 \mathrm{AR}}$ s located on GABAergic interneurons in the MPFC [136] and consequently 
stimulates pyramidal glutamatergic neurons [137], leading to opposing changes in DA outflow from the mPFC and Acb through direct or indirect interactions with DA VTA neurons [58]. This suggests a functional role for a specific $5-\mathrm{HT}_{2 \mathrm{BR}}$ population in the regulatory control of DA neuronal activity. Although the cellular mechanisms involved in this interaction have not yet been established, it is noteworthy that $5-\mathrm{HT}_{2 \mathrm{BR}} \mathrm{s}$ exert independent control over the activity of three ascending DA pathways through specific tonic excitatory and inhibitory control of DA efflux from the Acb and mPFC, and that there is no effect in the striatum.

\section{CONCLUSIONS}

Research over the years has led to significant advances in the understanding of serotonergic mechanisms involved in the effects of psychostimulants. So far, it has been established that pharmacologically decreasing or increasing the activity of the 5-HT system leads to an increase or decrease in the addictive effects of psychostimulants. Studies using 5-HT receptor ligands have provided much interesting information. There are suggestions that $5-\mathrm{HT}_{1 \mathrm{~B}}$ receptors undergo bidirectional, abstinencedependent changes. While $5-\mathrm{HT}_{1 \mathrm{~B}}$ receptor agonists administered to Acb during self-administration increase cocaine reinforcement, they decrease cocaine-seeking and the reoccurrence of cocaine-seeking behavior when administered during abstinence.

In contrast, separate populations of $5-\mathrm{HT}_{2 \mathrm{AR}}$ and 5- $\mathrm{HT}_{2 \mathrm{CR}}$ within the $\mathrm{PFC}, \mathrm{Acb}$, and VTA differentially affect the output of the mesocorticoaccumbens DA pathway. These studies indicate that the VTA is a brain site upon which 5- $\mathrm{HT}_{2 \mathrm{AR}}$ exerts an excitatory effect on cocaineinduced behavior, whereas the PFC is a specific brain site upon which $5-\mathrm{HT}_{2 \mathrm{CR}}$ exerts an inhibitory effect on cocaine-induced behavioral responses. In contrast, $5-\mathrm{HT}_{2 \mathrm{BR}}$ exert independent control over the three ascending DA pathways' activity through specific tonic excitatory and inhibitory control of DA efflux from the Acb and mPFC, with no effect in the striatum. These findings indicate that by manipulating the activity of the serotonergic system we can increase and, more importantly from a therapeutic point of view, decrease the effects of psychostimulants. However, many substances with therapeutic potential, such as $5-\mathrm{HT}_{2 \mathrm{BR}}$ ligands, show strong side effects. Despite considerable progress, the current state of knowledge does not translate into efficacy in the treatment of addiction, and we still do not have an effective pharmacotherapy. This may be because we study selected elements of a very complex system and do not cover the entire cascade of events caused by acting on a selected point of this complex machinery.

\section{Conflict of interest/Konflikt interesu}

Absent./Nie występuje.

Financial support/Finansowanie

This study was supported by the National Science Centre of Poland, Cracow, Poland, grant No. UMO- 2015/19/B/ NZ7/03610, and by the Institute of Psychiatry and Neurology, Warsaw, Poland, statutory fund No. 501-40-00318017-01.

\section{References/Piśmiennicłwo}

1. Koob GF, Volkow ND. Neurocircuitry of addiction. Neuropsychopharmacology 2010; 35: 217-238.

2. Foley KF. Mechanism of action and therapeutic uses of psychostimulants. Clin Lab Sci 2005; 18: 107-113.

3. Björklund A, Dunnett SB. Dopamine neuron systems in the brain: an update. Trends Neurosci 2007; 30: 194-202.

4. Tzschentke TM. Pharmacology and behavioral pharmacology of the mesocortical dopamine system. Prog Neurobiol 2001; 63: 241-320.

5. Bossert JM, Wihbey KA, Pickens CL, Nair SG, Shaham Y. Role of dopamine D(1)-family receptors in dorsolateral striatum in context-induced reinstatement of heroin seeking in rats. Psychopharmacology 2009; 206: 51-60.

6. Grüsser SM, Wrase J, Klein S, Hermann D, Smolka MN, Ruf M, et al. Cue induced activation of the striatum and medial prefrontal cortex is associated with subsequent relapse in abstinent alcoholics. Psychopharmacology 2004; 175: 296-302.

7. McClernon FJ, Kozink RV, Lutz AM, Rose JE. 24-h smoking abstinence potentiates fMRI-BOLD activation to smoking cues in cerebral cortex and dorsal striatum. Psychopharmacology 2009; 204: 25-35.

8. Pierce RC, Vanderschuren LJ. Kicking the habit: the neural basis of ingrained behaviors in cocaine addiction. Neurosci Biobehav Rev 2010; 35: 212-219. 
9. Volkow ND, Fowler JS, Wang GJ. The addicted human brain: insights from imaging studies. J Clin Invest 2003; 111: 1444-1451.

10. Caine SB, Thomsen M, Gabriel KI, Berkowitz JS, Gold LH, Koob GF, et al. Lack of self-administration of cocaine in dopamine D1 receptor knock-out mice. J Neurosci 2007; 27: 13140-13150.

11. Zweifel LS, Parker JG, Lobb CJ, Rainwater A, Wall VZ, Fadok JP, et al. Disruption of NMDAR-dependent burst firing by dopamine neurons provides selective assessment of phasic dopamine-dependent behavior. Proc Natl Acad Sci U S A 2009; 106: 7281-7288.

12. Norman AB, Tabet MR, Norman MK, Fey BK, Tsibulsky VL, Millard RW. The affinity of D2-like dopamine receptor antagonists determines the time to maximal effect on cocaine self-administration. J Pharmacol Exp Ther 2011; 338: 724-728.

13. Caine SB, Negus SS, Mello NK, Patel S, Bristow L, Kulagowski J, et al. Role of dopamine D2-like receptors in cocaine self-administration: studies with D2 receptor mutant mice and novel D2 receptor antagonists. J Neurosci 2002; 22: 2977-2988.

14. Durieux PF, Bearzatto B, Guiducci S, Buch T, Waisman A, Zoli M, et al. D2R striatopallidal neurons inhibit both locomotor and drug reward processes. Nat Neurosci 2009; 12: 393-395.

15. Koob GF, Volkow ND. Neurobiology of addiction: a neurocircuitry analysis. Lancet Psychiatry 2016; 3: 760-773.

16. Kalivas PW, Volkow ND. The neural basis of addiction: a pathology of motivation and choice. Am J Psychiatry 2005; 162: 1403-1413.

17 Feil J, Sheppard D, Fitzgerald PB, Yucel M, Lubman DI, Bradshaw JL. Addiction, compulsive drug seeking, and the role of frontostriatal mechanisms in regulating inhibitory control. Neurosci Biobehav Rev 2010; 35: 248-275.

18. Everitt BJ, Wolf ME. Psychomotor stimulant addiction: a neural systems perspective. J Neurosci 2002; 22: 3312-3320.

19. Kelley AE. Memory and addiction: shared neural circuitry and molecular mechanisms. Neuron 2004; 44: 161-179.

20. Berridge KC, Robinson TE, Aldridge JW. Dissecting components of reward: 'liking', 'wanting', and learning. Curr Opin Pharmacol 2009; 9: 65-73.

21. Nakamura K, Matsumoto M, Hikosaka O. Reward-dependent modulation of neuronal activity in the primate dorsal raphe nucleus. J Neurosci 2008; 28: 5331-5343.

22. Ranade SP, Mainen ZF. Transient firing of dorsal raphe neurons encodes diverse and specific sensory, motor, and reward events. J Neurophysiol 2009; 102: 3026-3037.

23. Cunningham KA, Anastasio NC. Serotonin at the nexus of impulsivity and cue reactivity in cocaine addiction. Neuropharmacology 2014; 76: 460-478

24. Müller CP, Homberg J. The role of serotonin in drug use and addiction. Behav Brain Res 2015; 277: 146-192.

25. Azmitia EC, Segal M. An autoradiographic analysis of the differential ascending projections of the dorsal and median raphe nuclei in the rat. J Comp Neurol 1978; 179: 641-667.

26. Jacobs BL, Azmitia EC. Structure and function of the brain serotonin system. Physiol Rev 1992; 7: 165-229.

27. Boileau I, Dagher A, Leyton M, Welfeld K, Booij L, Diksic M, et al. Conditioned dopamine release in humans: a positron emission tomography [11C]raclopride study with amphetamine. J Neurosci 2007; 27: 3998-4003.

28. Volkow ND, Wang GJ, Telang F, Fowler JS, Logan J, Childress AR, et al. Cocaine cues and dopamine in dorsal striatum: mechanism of craving in cocaine addiction. J Neurosci 2006; 26: 6583-6588.

29. Coleman JA, Yang D, Zhao Z, Wen PC, Yoshioka C, Tajkhorshid E, Gouaux E. Serotonin transporter-ibogaine complexes illuminate mechanisms of inhibition and transport. Nature 2019; 569: 141-145.

30. Koe BK. Molecular geometry of inhibitors of the uptake of catecholamines and serotonin in synaptosomal preparations of rat brain. J Pharmacol Exp Ther 1976; 199: 649-661.

31. Cunningham KA, Lakoski JM. The interaction of cocaine with serotonin dorsal raphe neurons: Single unit extracellular recording studies. Neuropsychopharmacol 1990; 3: 41-50.

32. Pitts DK, Marwah J. Electrophysiological effects of cocaine on central monoaminergic neurons. Eur J Pharmacol 1986; 131: 95-98.

33. Bradberry CW, Nobiletti JB, Elsworth JD, Murphy B, Jatlow P, Roth RH. Cocaine and cocaethylene: microdialysis comparison of brain drug levels and effects on dopamine and serotonin. J Neurochem 1993; 60: 1429-1435.

34. Parsons LH, Justice JB Jr. Serotonin and dopamine sensitization in the nucleus accumbens, ventral tegmental area, and dorsal raphe nucleus following repeated cocaine administration. J Neurochem 1993; 61: 1611-1619.

35. Pum M, Carey RJ, Huston JP, Muller CP. Dissociating effects of cocaine and d-amphetamine on dopamine and serotonin in the perirhinal, entorhinal, and prefrontal cortex of freely moving rats. Psychopharmacology (Berl) 2007; 193: 375-390.

36. Bromberg-Martin ES, Hikosaka O, Nakamura K. Coding of task reward value in the dorsal raphe nucleus. J Neurosci 2010; 30: 6262-6272.

37. Inaba M, Maruyama T, Yoshimura Y, Hosoi H, Komatsu Y. Facilitation of low-frequency stimulation induced long-term potentiation by endogenous noradrenaline and serotonin in developing rat visual cortex. Neurosci Res 2009; 64: 191-198.

38. Miyazaki K, Miyazaki KW, Doya K. Activation of dorsal raphe serotonin neurons underlies waiting for delayed rewards. J Neurosci 2011; 31: 469-479.

39. Miyazaki KW, Miyazaki K, Doya K. Activation of the central serotonergic system in response to delayed but not omitted rewards. Eur J Neurosci 2011; 33: 153-160.

40. Andrews CM, Lucki I. Effects of cocaine on extracellular dopamine and serotonin levels in the nucleus accumbens. Psychopharmacology (Berl) 2001; 155: 221-229. 
41. Müller CP, Carey RJ, De Souza Silva MA, Jocham G, Huston JP. Cocaine increases serotonergic activity in the hippocampus and nucleus accumbens in vivo:5-HT1a-receptor antagonism blocks behavioral but potentiates serotonergic activation. Synapse 2002; 45: 67-77.

42. Sizemore GM, Co C, Smith JE. Ventral pallidal extracellular fluid levels of dopamine, serotonin, gamma amino butyric acid, and glutamate during cocaine self-administration in rats. Psychopharmacology (Berl) 2000; 150: 391-398.

43. Müller CP, Thönnessen H, Barros M, Tomaz C, Carey RJ, Huston JP. Hippocampus 5-HT(1A)-receptors attenuate cocaine-induced hyperlocomotion and the increase in hippocampal but not nucleus accumbens 5-HT. Hippocampus 2004; 14: 710-721.

44. Rutter JJ, Baumann MH, Waterhouse BD. Systemically administered cocaine alters stimulus-evoked responses of thalamic somatosensory neurons to peri threshold vibrissae stimulation. Brain Res 1998; 798: 7-17.

45. Reith ME, Li MY, Yan QS. Extracellular dopamine, norepinephrine, and serotonin in the ventral tegmental area and nucleus accumbens of freely moving rats during intracerebral dialysis following systemic administration of cocaine and other uptake blockers. Psychopharmacology 1997; 134: 309-317.

46. Mangiavacchi S, Masi F, Scheggi S, Leggio B, De Montis MG, Gambarana C. Long-term behavioral and neurochemical effects of chronic stress exposure in rats. J Neurochem 2001; 79: 1113-1121.

47. Müller CP, Carey RJ, Huston JP, De Souza Silva MA. Serotonin and psychostimulant addiction: focus on 5-HT1Areceptors. Prog Neurobiol 2007; 81: 133-178.

48. Baumann MH, Williams Z, Zolkowska D, Rothman RB. Serotonin (5-HT)precursor loading with 5-hydroxy1-tryptophan (5-HTP) reduces locomotor activation produced by (+)-amphetamine in the rat. Drug Alcohol Depend 2011; 114: 147-152.

49. Kankaanpaa A, Meririnne E, Lillsunde P, Seppala T. The acute effects ofamphetamine derivatives on extracellular serotonin and dopamine levels inrat nucleus accumbens. Pharmacol Biochem Behav 1998; 59: 1003-1009.

50. Kuczenski R, Segal DS, Cho AK, Melega W. Hippocampus norepinephrine, caudate dopamine and serotonin, and behavioral-responses to the stereoisomers of amphetamine and methamphetamine. J Neurosci 1995; 15: 1308-1317.

51 Yubero-Lahoz S, Ayestas Jr MA, Blough BE, Partilla JS, Rothman RB, de la TorreR, et al. Effects of MDMA and related analogs on plasma 5-HT: relevance to5-HT transporters in blood and brain. Eur J Pharmacol 2012; 674: 337-344.

52. Millan MJ, Brocco M, Gobert A, Joly F, Bervoets K, Rivet JM, et al. Contrasting mechanisms of action and sensitivity to antipsychotics of phencyclidine versus amphetamine: importance of nucleus accumbens 5-HT2A sites for PCP-induced locomotion in the rat. Eur J Neurosci 1999; 11: 4419-4432.

53. Pum ME, Carey RJ, Huston JP, Müller CP. Role of medial prefrontal, entorhinal, and occipital 5-HT in cocaine-induced place preference and hyperlocomotion: evidence for multiple dissociations. Psychopharmacology (Berl) 2008; 201: 391-403.

54. Ferre S, Cortes R, Artigas F. Dopaminergic regulation of the serotonergic raphe-striatal pathway - microdialysis studies in freely moving rats. J Neurosci 1994; 14: 4839-4846.

55. Dawson LA, Nguyen HQ, Li P. Potentiation of amphetamine-induced changes in dopamine and 5-HT by a 5-HT6 receptor antagonist. Brain Res Bull 2003; 59: 513-521.

56. Hedou G, Homberg J, Martin S, Wirth K, Feldon J, Heidbreder CA. Effect ofamphetamine on extracellular acetylcholine and monoamine levels in subter-ritories of the rat medial prefrontal cortex. Eur J Pharmacol 2000; 390: 127-136.

57. West WB, Van Groll BJ, Appel JB. Stimulus effects of d-amphetamine II: DA,NE, and 5-HT mechanisms. Pharmacol Biochem Behav 1995; 51: 69-76.

58. Devroye C, Haddjeri N, Cathala A, Rovera R, Drago F, Piazza PV, et al. Opposite control of mesocortical and mesoaccumbal dopamine pathways by serotonin2B receptor blockade: Involvement of medial prefrontal cortex serotonin1A receptors. Neuropharmacology 2017; 119: 91-99.

59. Rueter LE, Fornal CA, Jacobs BL. A critical review of 5-HT brain microdialysis and behavior. Rev Neurosci 1997; 8: 117-137.

60. Leyton M, Vezina P. Dopamine ups and downs in vulnerability to addictions: a neurodevelopmental model. Trends in Pharmacological Sciences 2011; 35: 268-276.

61. Svingos AL, Hitzemann R. 5-HT3 receptor antagonists block cocaine-induced locomotion via a PCPA-sensitive mechanism. Pharmacol Biochem Behav 1992; 43: 871-879.

62. Herges S, Taylor DA. Involvement of serotonin in the modulation of cocaine-induced locomotor activity in the rat. Pharmacol Biochem Behav 1998; 59: 595-611.

63. Morrow BA, Roth RH. Serotonergic lesions alter cocaine-induced locomotor behavior and stress-activation of the mesocorticolimbic dopamine system. Synapse 1996; 23: 174-181.

64. Roberts DCS, Loh EA, Baker GB, Vickers G. Lesions of central serotonin systems affect responding on a progressive ratio schedule reinforced either by intravenous cocaine or by food. Pharmacol Biochem Behav 1994; 49: 177-182.

65. Loh EA, Roberts DC. Breakpoints on a progressive ratio schedule reinforced by intravenous cocaine increase following depletion of forebrain serotonin. Psychopharmacology 1990; 101: 262-266.

66. Pum ME, Huston JP, De Souza Silva MA, Müller CP. Visual sensory-motor gating by serotonin activation in the medial prefrontal and occipital, but not intherhinal, cortices in rats. Neuroscience 2008; 153: 361-372.

67. Carta M, Collu M, Fadda F, Stancampiano R. Augmented cocaine-induced accumbal dopamine efflux, motor activity and place preference in rats fed with a tryptophan-deficient diet. Neurosci Lett 2006; 401: 125-129. 
68. Carta M, Fadda F, Stancampiano R. Tryptophan-deficient diet increases the neurochemical and behavioral response to amphetamine. Brain Res 2006; 1094: 86-91.

69. Cox SM, Benkelfat C, Dagher A, Delaney JS, Durand F, Kolivakis T, et al. Effects of lowered serotonin transmission on cocaine-induced striatal dopamine response: PET $\left[{ }^{11} \mathrm{C}\right]$ raclopride study in humans. Br J Psychiatry 2011; 199: 391-397.

70. Aronson SC, Black JE, Mcdougle CJ, Scanley BE, Jatlow P, Kosten TR, et al. Serotonergic mechanisms of cocaine effects in humans. Psychopharmacology (Berl) 1995; 119: 179-185.

71. Robinson TE, Berridge KC. The incentive sensitization theory of addiction: some current issues. Philos Trans R Soc Lond B Biol Sci 2008; 363: 3137-3146.

72. Phillips AG, Vacca G, Ahn S. A top-down perspective on dopamine, motivation and memory. Pharmacol Biochem Behav 2008; 90: 236-249.

73. Everitt BJ, Robbins TW. Neural systems of reinforcement for drug addiction: from actions to habits to compulsion. Nat Neurosci 2005; 8: 1481-1489.

74. Haber SN, Kim KS, Mailly P, Calzavara R. Reward-related cortical inputs define a large striatal region in primates that interface with associative cortical connections, providing a substrate for incentive-based learning. J Neurosci 2006; 26: 8368-8376.

75. Filip M, Alenina N, Bader M, Przegalinski E. Behavioral evidence for the significance of serotoninergic (5-HT) receptors in cocaine addiction. Addict Biol 2010; 15: 227-249.

76. Czoty PW, Ginsburg BC, Howell LL. Serotonergic attenuation of the reinforcing and neurochemical effects of cocaine in squirrel monkeys. J Pharmacol Exp Ther 2002; 300: 831-837.

77. Peltier R, Schenk S. Effects of serotonergic manipulations on cocaine self-administration in rats. Psychopharmacology (Berl) 1993; 110: 390-394.

78. Pradhan S, Roy SN, Pradhan SN. Correlation of behavioral and neurochemical effects of acute administration of cocaine in rats. Life Sci 1978; 22: 1737-1743.

79. Molina PE, Ahmed N, Gatley J, Volkow ND, Abumrad NN. L-tryptophan attenuation of the dopaminergic and behavioral responses to cocaine. Life Sci 2001; 69: 1897-1906.

80. McGregor A, Lacosta S, Roberts DC. 1-Tryptophan decreases the breaking point under a progressive ratio schedule of intravenous cocaine reinforcement in the rat. Pharmacol Biochem Behav 1993; 44: 651-655.

81. Glowa JR, Rice KC, Matecka D, Rothman RB. Phentermine/fenfluramine decreases cocaine selfadministration in rhesus monkeys. Neuroreport 1997 ;8: 1347-1351.

82. Carroll ME, Lac ST, Asencio M, Kragh R. Fluoxetine reduces intravenous cocaine self-administration in rats. Pharmacol Biochem Behav 1990; 35: 237-244.

83. Richardson NR, Roberts DCS. Fluoxetine pretreatment reduces breaking points on a progressive ratio schedule reinforced by intravenous cocaine self-administration in the rat. Life Sci 1991; 49: 833-840.

84. Bubar MJ, McMahon LR, De Deurwaerdere P, Spampinato U, Cunningham KA. Selective serotonin reuptake inhibitors enhance cocaine-induced locomotor activity and dopamine release in the nucleus accumbens. Neuropharmacology 2003; 44: 342-353.

85. Fletcher PJ, Chintoh AF, Sinyard J, Higgins GA. Injection of the 5-HT2C receptor agonist Ro60-0175 into the ventral tegmental area reduces cocaine-induced locomotor activity and cocaine self-administration. Neuropsychopharmacology 2004; 29: 308-318.

86. Kohut SJ, Fivel PA, Blough BE, Rothman RB, Mello NK. Effects of meth-cathinone and 3-Cl-methcathinone (PAL-434) in cocaine discrimination or self-administration in rhesus monkeys. Int J Neuropsychopharmacol 2013; 16: 1985-1998.

87. Homberg JR, De Boer SF, Raaso HS, Olivier JD, Verheul M, Ronken E, et al. Adaptations in pre- and postsynaptic 5-HT1A receptor function and cocaine supersensitivity in serotonin transporter knockout rats. Psychopharmacology (Berl) 2008; 200: 367-380.

88. Sora I, Hall FS, Andrews AM, Itokawa M, Li XF, Wei HB, et al. Molecular mechanisms of cocaine reward: combined dopamine and serotonin transporter knockouts eliminate cocaine place preference. Proc Natl Acad Sci U S A 2001; 98: 5300-5305.

89. Thomsen M, Hall FS, Uhl GR, Caine SB. Dramatically decreased cocaine self-administration in dopamine but not serotonin transporter knock-out mice. J Neurosci 2009; 29: 1087-1092.

90. Homberg JR, Olivier JD, Smits BM, Mul JD, Mudde J, Verheul M, et al. Characterization of the serotonin transporter knockout rat: a selective change in the functioning of the serotonergic system. Neuroscience 2007; 146: 1662-1676.

91. Olivier JD, Van Der Hart MG, Van Swelm RP, Dederen PJ, Homberg JR, Cremers T, et al. A study in male and female 5-HT transporter knockout rats: an animal model for anxiety and depression disorders. Neuroscience 2008; 152: 573-584.

92. Bruinvels AT, Palacios JM, Hoyer D. Autoradiographic characterisation and localisation of 5-HT1D compared to 5-HT1B binding sites in rat brain. Naunyn Schmiedebergs Arch Pharmacol 1993; 347: 569-582.

93. Sari Y. Serotonin1B receptors: from protein to physiological function and behavior. Neurosci Biobehav Rev $2004 ; 28: 565-582$.

94. Hjorth S, Tao R. The putative 5-HT1B receptor agonist CP-93,129 suppresses rat hippocampal 5-HT release in vivo: comparison with RU 24969. Eur J Pharmacol 1991; 209: 249-252.

95. Sharp T, Bramwell SR, Grahame-Smith DG. 5-HT1 agonists reduce 5-hydroxytryptamine release in rat hippocampus in vivo as determined by brain microdialysis. Br J Pharmacol 1989; 96: 283-290. 
96. Morikawa H, Manzoni OJ, Crabbe JC, Williams JT. Regulation of central synaptic transmission by 5-HT1B autoand heteroreceptors. Mol Pharmacol 2000; 58: 1271-1278.

97. Yan QS, Zheng SZ, Yan SE. Involvement of 5-HT1B receptors within the ventral tegmental area in regulation of mesolimbic dopaminergic neuronal activity via GABA mechanisms: a study with dual-probe microdialysis. Brain Res 2004; 1021: 82-91.

98. Miszkiel J, Jastrzębska J, Filip M, Przegaliński E. Amphetamine self-administration and its extinction alter the 5-HT1b receptor protein levels in designated structures of the rat brain. Neurotox Res 2019; 35: 217-229.

99. Bockaert J, Claeysen S, Becamel C, Dumuis A, Marin P. Neuronal 5-HT metabotropic receptors: fine tuning of their structure, signaling, and roles in synaptic modulation. Cell Tissue Res 2006; 326: 553-572.

100. Hoyer D, Hannon JP, Martin GR. Molecular, pharmacological and functional diversity of 5-HT receptors. Pharmacol Biochem Behav 2002; 71: 533-554.

101. Gurevich I, Tamir H, Arango V, Dwork AJ, Mann JJ, Schmauss C. Altered editing of serotonin 2C receptor premRNA in the prefrontal cortex of depressed suicide victims. Neuron 2002; 34: 349-356.

102. Anastasio NC, Stutz SJ, Fox RG, Sears RM, Emeson RB, Di Leone RJ, et al. Functional status of the serotonin 5-HT2C receptor (5-HT2CR) drives interlocked phenotypes that precipitate relapse-like behaviors in cocaine dependence. Neuropsychopharmacology 2014; 39: 370-382.

103. Hannon J, Hoyer D. Molecular biology of 5-HT receptors. Behav Brain Res 2008; 195: 198-213.

104. Castanon N, Scearce-Levie K, Lucas JJ, Rocha B, Hen R. Modulation of the effects of cocaine by 5-HT1B receptors:a comparison of knockouts and antagonists. Pharmacol Biochem Behav 2000; 67: 559-566.

105. Miszkiel J, Filip M, Przegaliński E. Role of serotonin (5-HT)1B receptors in psychostimulant addiction. Pharmacol Rep 2011; 63: 1310-1315.

106. Przegaliński E, Siwanowicz J, Nowak E, Papla I, Filip M. Role of 5-HT1B receptors in the sensitization to amphetamine in mice. Eur J Pharmacol 2001; 422: 91-99.

107. Neumaier JF, Vincow ES, Arvanitogiannis A, Wise RA, Carlezon WA Jr. Elevated expression of 5-HT1B receptors in nucleus accumbens efferents sensitizes animals to cocaine. J Neurosci 2002; 22: 10856-10863.

108. Parsons LH, Weiss F, Koob GF. Serotonin1B receptor stimulation enhances cocaine reinforcement. J Neurosci 1998; 18: 10078-10089.

109. Przegaliński E, Gołda A, Frankowska M, Zaniewska M, Filip M. Effects of serotonin 5-HT1B receptor ligands on the cocaine- and food-maintained self-administration in rats. Eur J Pharmacol 2007; 559: 165-172.

110. Fletcher PJ, Korth KM. Activation of 5-HT1B receptors in the nucleus accumbens reduces amphetamine-induced enhancement of responding for conditioned reward. Psychopharmacology (Berl) 1999; 142: 165-174.

111. Acosta JI, Boynton FA, Kirschner KF, Neisewander JL. Stimulation of 5-HT1B receptors decreases cocaine- and sucrose-seeking behavior. Pharmacol Biochem Behav 2005; 80: 297-307.

112. Przegaliński E, Gołda A, Filip M. Effects of serotonin (5-HT)1B receptor ligands on cocaine-seeking behavior in rats. Pharmacol Rep 2008; 60: 798-810.

113. O'Dell LE, Manzardo AM, Polis I, Stouffer DG, Parsons LH. Biphasic alterations in serotonin-1B (5-HT1B) receptor function during abstinence from extended cocaine self-administration. J Neurochem 2006; 99: 1363-1376.

114. Neisewander JL, Cheung THC, Pentkowski NS. Dopamine D3 and 5-HT1B receptor dysregulation as a result of psychostimulant intake and forced abstinence: implications for medications development. Neuropharmacology 2014; 76 Pt B (0 0): 301-319.

115. Pentkowski N, Harder BG, Brunwasser SJ, Bastle RM, Peartree NA, Yanamandra K, et al. Pharmacological evidence for an abstinence-induced switch in 5-HT1b receptor modulation of cocaine self-administration and cocaine-seeking behavior. Chem Neurosci 2014; 5: 168-176.

116. Bubar MJ, Cunningham KA. Prospects for serotonin 5-HT2R pharmacotherapy in psychostimulant abuse. In: Di Giovanni G, Di Matteo V, Esposito E (eds.). Progress in Brain Research, Vol. 172. Rounsaville: Elsevier Science; 2008.

117. De Deurwaerdere P, Navailles S, Berg KA, Clarke WP, Spampinato U. Constitutive activity of the serotonin2C receptor inhibits in vivo dopamine release in the rat striatum and nucleus accumbens. J Neurosci 2004; 24: 32353241.

118. Broderick PA, Olabisi OA, Rahni DN, Zhou Y. Cocaine acts on accumbens monoamines and locomotor behavior via a 5-HT2A/2C receptor mechanism as shown by ketanserin: 24 -h follow-up studies. Prog Neuropsychopharmacol Biol Psychiatry 2004; 28: 547-557.

119. Auclair A, Blanc G, Glowinski J, Tassin JP. Role of serotonin $2 A$ receptors in the D-amphetamine induced release of dopamine: comparison with previous data on alphalb-adrenergic receptors. J Neurochem 2004; 91: 318-326.

120. Cunningham KA, Callahan PM. Neurobehavioral pharmacology of cocaine: role for serotonin in its locomotor and discriminative stimulus effects. In: Erinoff L, Brown RM (eds.). Neurobiological Models for Evaluating Mechanisms Underlying Cocaine Addiction. US Government Printing Office; 1994, pp. 40-66.

121. McCreary AC, Cunningham KA. The effects of the 5-HT2C/2B antagonist SB 206553 on cocaine-induced locomotor activity. Neuropsychopharmacology 1999; 20: 556-564.

122. Fletcher PJ, Grottick AJ, Higgins GA. Differential effects of the 5-HT2A receptor antagonist M100,907 and the 5-HT2C receptor antagonist SB242,084 on cocaine-induced locomotor activity, cocaine self-administration and cocaine-induced reinstatement of responding. Neuropsychopharmacology 2002; 27: 576-586.

123. Filip M, Bubar MJ, Cunningham KA. Contribution of serotonin (5-hydroxytryptamine; 5-HT) 5-HT2 receptor subtypes to the hyperlocomotor effects ofcocaine: acute and chronic pharmacological analyses. J Pharmacol Exp Ther 2004; 310: 1246-1254. 
124. Filip M, Bubar MJ, Cunningham KA. Contribution of serotonin (5-HT) 5-HT2 receptor subtypes to the discriminative stimulus effects of cocaine in rats. Psychopharmacology 2006; 183: 482-489.

125. Schmidt CJ, Black CK, Taylor VL, Fadayel GM, Humphreys TM, Nieduzak TR, Sorensen SM. The 5-HT2 receptor antagonist, MDL 28,133A,disrupts the serotonergic-dopaminergic interaction mediating the neurochemical effects of 3,4-methylenedioxymethamphetamine. Eur J Pharmacol 1992; 220: 151-159.

126. Fletcher PJ, Sinyard J, Higgins GA. The effects of the 5-HT(2C) receptor antagonist SB242084 on locomotor activity induced by selective, or mixed, indirect serotonergic and dopaminergic agonists. Psychopharmacology (Berl.) 2006; 187: 515-525.

127. McCreary AC, Bankson MG, Cunningham KA. Pharmacological studies of the acute and chronic effects of (+)-3,4-methylenedioxymethamphetamine on locomotor activity: role of 5-hydroxytryptamine1A and 5-hydroxytryptamine1B/1D receptors. J Pharmacol Exp Ther 1999; 290: 965-973.

128. Bankson MG, Cunningham KA. Pharmacological studies of the acute effects of (+)-3,4- methylenedioxymethamphetamine on locomotor activity: role of 5-HT(1B/1D) and 5-HT(2) receptors. Neuropsychopharmacology 2002; 26: 40-52.

129. McMahon LR, Filip M, Cunningham KA. Differential regulation of the mesoaccumbens circuit by serotonin 5-hydroxytryptamine (5-HT)2A and 5-HT2C receptors. J Neurosci 2001; 21: 7781-7787.

130. Filip M, Cunningham KA. Serotonin 5-HT(2C) receptors in nucleus accumbens regulate expression of the hyperlocomotive and discriminative stimulus effects of cocaine. Pharmacol Biochem Behav 2002; 71: 745-756.

131. Filip M, Cunningham KA. Hyperlocomotive and discriminative stimulus effects of cocaine are under the control of serotonin(2C) (5-HT(2C)) receptors in rat prefrontal cortex. J Pharmacol Exp Ther 2003; 306: 734-743.

132. Szucs RP, Frankel PS, McMahon LR, Cunningham KA. Relationship of cocaine-induced c-Fos expression to behaviors and the role of serotonin 5-HT2A receptors in cocaine-induced c-Fos expression. Behav Neurosci 2005; 119: 1173-1183.

133. McMahon LR, Cunningham KA. Role of $5-\mathrm{HT}(2 \mathrm{a})$ and $5-\mathrm{HT}(2 \mathrm{~B} / 2 \mathrm{C})$ receptors in the behavioral interactions between serotonin and catecholamine reuptake inhibitors. Neuropsychopharmacology 2001; 24: 319-329.

134. Liu S, Bubar MJ, Lanfranco MF, Hillman GR, Cunningham KA. Serotonin(2C) receptor localization in GABA neurons of the rat medial prefrontal cortex: implications for understanding the neurobiology of addiction. Neuroscience 2007; 146: 1667-1688.

135. Devroye C, Cathala A, Piazza PV, Spampinato U. The central serotonin2B receptor as a new pharmacological target for the treatment of dopamine-related neuropsychiatric disorders: rationale and current status of research. Pharmacol Ther 2018; 181: 143-155.

136. Santana N, Bortolozzi A, Serrats J, Mengod G, Artigas F. Expression of serotonin1A and serotonin2A receptors in pyramidal and GABAergic neurons of the rat prefrontal cortex. Cereb Cortex 2004; 14: 1100-1109.

137. Lladó-Pelfort L, Santana N, Ghisi V, Artigas F, Celada P. 5-HT1A receptor agonists enhance pyramidal cell firing in prefrontal cortex through a preferential action on GABA interneurons. Cereb Cortex 2012; 22: 1487-1497. 